CATAR, G. 1972. Studies on toxoplasmosis as regards its natural focality in Slovakia. Folia Parasitologica (Praha) 19: 253-256.

Chomel, B. B., M. L. Carniciu, R. W. Kasten, P. M. Castelli, T. M. WorK, AND D. A. JESSUP. 1994. Antibody prevalence of eight ruminant infectious diseases in California mule and black-tailed deer (Odocoileus hemionus). Journal of Wildlife Diseases 30: 51-59.

DubeY, J. P., 2003. Reveiw of Neospora caninum and neosporosis in animals. Korean Journal of Parasitology 41: 1-16.

, AND C. P. BEATTIE. 1988. Toxoplasmosis of animals and man. CRC Press, Boca Raton, Florida, 220 p.

- , K. Hollis, S. Romand, P. Thulliez, O. C. H. KwoK, L. HunGERFORD, C. ANCHOR, AND D. ETTER. 1999. High prevalence of antibodies to Neospora caninum in white-tailed deer (Odocoileus virginianus). Journal of Parasitology 29: 1709-1711.

_ AND P. Thulliez. 2005. Prevalence of antibodies to Neospora caninum in wild animals. Journal of Parasitology 91: 1217-1218.

Ferreira, R. A., J. R. Mineo, J. M. Duarte, D. A. O. Silva, and J. H. PATARROYo. 1997. Toxoplasmosis in naturally infected deer from Brazil. Journal of Wildlife Diseases 33: 896-899.

Ferroglio, E., B. Bassano, A. Trisciuoglio, and L. Rossi. 2001. Antibodies to Neospora caninum in Alpine ibex from the Italian Alps. Zeitschrift fur Jagdwissenschaft 47: 226-228.

, AND L. Rossi. 2001. Prevalence of Neospora caninum antibodies in wild ruminants from the Italian Alps. Veterinary Record 148: 754-755.

Gauss, C. B. L., J. P. Dubey, D. Vidal, O. Cabezon, F. Ruiz-Fons, J. Vicente, I. Marco, S. Lavin, C. Gortazar, AND S. Almeria. 2006. Prevalence of Toxoplasma gondii antibodies in red deer (Cervus elaphus) and other wild ruminants from Spain. Veterinary Parasitology 136: 193-200.

Gondim, L. F. P. 2006. Neospora caninum in wildlife. Trends in Parasitology 22: 247-252.

, M. M. McAllister, N. E. Mateus-Pinilla, W. C. Pitt, L. D. Mech, and M. E. Nelson. 2004. Transmission of Neospora caninum between wild and domestic animals. Journal of Parasitology 90: $1361-1365$.

W. C. Pitt, And D. E. ZemLicka. 2004. Coyotes (Canis latrans) are definitive hosts of Neospora caninum. International Journal for Parasitology 34: 159-161.

HeJlíček, K., I. LiteráK, AND J. Nezval. 1997. Toxoplasmosis in wild mammals from the Czech Republic. Journal of Wildlife Diseases 33: $480-485$.
KAPPERUD, G. 1978. Survey for toxoplasmosis in wild and domestic animals from Norway and Sweden. Journal of Wildlife Diseases 14: $157-162$.

Kutz, S. J., B. Elkin, A. Gunn, And J. P. Dubey. 2000. Prevalence of Toxoplasma gondii antibodies in muskox (Ovibos moschatus) sera from Northern Canada. Journal of Parasitology 86: 879-882.

, D. PANAYI, AND J. P. DUBEy. 2001. Prevalence of Toxoplasma gondii antibodies in barren-ground caribou (Rangifer tarandus groenlandicus) from the canadian arctic. Journal of Parasitology 87: 439-442.

Lindsay, D. S., B. L. Blagburn, J. P. Dubey, and W. H. Mason. 1991. Prevalence and isolation of Toxoplasma gondii from white-tailed deer in Alabama. Journal of Parasitology 77: 62-64.

, S. E. LitTle, AND W. R. DAvidson. 2002. Prevalence of antibodies to Neospora caninum in white-tailed deer, Odocoileus virginianus, from the southeastern United States. Journal of Parasitology 88: 415-417.

Oksanen, A., K. Asbakk, M. Mieminen, H. Norberg, and A. Nareaho. 1997. Antibodies against Toxoplasma gondii in Fennoscandian reindeer -Association with the degree of domestication. Parasitology International 46: 255-261.

Ross, R. D., L. A. Stec, J. C. Werner, M. S. Blumenkranz, L. Glazer, AND G. A. Williams. 2001. Presumed acquired ocular toxoplasmosis in deer hunters. Retina 21: 226-229.

Sacks, J. J., D. G. Delgado, H. O. Lobel, and R. L. Parker. 1983. Toxoplasmosis infection associated with eating undercooked venison. American Journal of Epidemiology 118: 832-838.

SROKA, J. 2001. Seroepidemiology of toxoplasmosis in the Lublin region. Annals of Agricultural and Environmental Medicine 8: 2531

Vikoren, T., J. Tharaldsen, B. Fredriksen, and K. Handeland. 2004. Prevalence of Toxoplasma gondii antibodies in wild red deer, roe deer, moose, and reindeer from Norway. Veterinary Parasitology 120: $159-169$.

Williamson, J. M. W., AND H. Williams. 1980. Toxoplasmosis in farmed red deer (Cervus elaphus) in Scotland. Research in Veterinary Science 29: 36-40.

Zarnke, R. L., J. P. Dubey, O. C. H. Kwok, And J. M. Hoef. 2000. Serologic survey for Toxoplasma gondii in selected wildlife species from Alaska. Journal of Wildlife Diseases 36: 219-224.

\title{
Survey of the Metazoan Ectoparasites of the European Flounder Platichthys flesus (Linnaeus, 1758) along the North-Central Portuguese Coast
}

Francisca I. Cavaleiro and Maria J. Santos*, Universidade do Porto, Faculdade de Ciências, Departamento de Zoologia-Antropologia, Praça Gomes Teixeira, 4099-002 Porto, Portugal, and CIMAR Laboratório Associado/CIIMAR, Centro Interdisciplinar de Investigação Marinha e Ambiental, Rua dos Bragas, 289, 4050-123 Porto, Portugal; *To whom correspondence should be addressed. e-mail: mjsantos@fc.up.pt

ABSTRACT: A survey was undertaken to identify metazoan ectoparasite species on the European flounder, Platichthys flesus (Linnaeus, 1758) in 4 different locations off the north-central Portuguese coast. Parasites of 7 different taxa were found: Caligus diaphanus, Caligus sp., and Lepeophtheirus pectoralis (Copepoda: Caligidae); Acanthochondria cornuta (Copepoda: Chondracanthidae); Holobomolochus confusus (Copepoda: Bomolochidae); Nerocila orbignyi (Isopoda: Cymothoidae); and praniza larvae (Isopoda: Gnathiidae). Lernaeocera branchialis, a common European flounder parasite in the North and Baltic Seas, was not observed among the surveyed fish. Caligus diaphanus, Caligus sp., and Nerocila orbignyi are new host records. The high prevalence and intensity values recorded for $L$. pectoralis and $A$. cornuta suggest that both parasite species are common to the European flounder along the north-central Portuguese coast. In contrast, infection levels with respect to the other parasite taxa were, in most cases, comparatively lower, thereby indicating that they only occur occasionally among flounders in the surveyed area.

The European flounder Platichthys flesus (Linnaeus, 1758) (Teleostei: Pleuronectidae) is a catadromous flatfish species that spends much of its life cycle in estuarine and brackish aquatic environments, going to the open sea to spawn in early spring. Its geographic distribution extends along the Atlantic coast, from the White Sea in the north, to northern Africa in the south, including also the Mediterranean and the Black seas (Lucas and Baras, 2001). It is an important species to the Portuguese fisheries, occurring along the entire coast of Portugal (Sobral and Gomes, 1997).

Several metazoan ectoparasite species have already been recorded on 
TABLE I. Metazoan ectoparasitic species recorded for the European flounder Platichthys flesus (Linnaeus, 1758) in different studies of the literature and respective prevalence values (range).

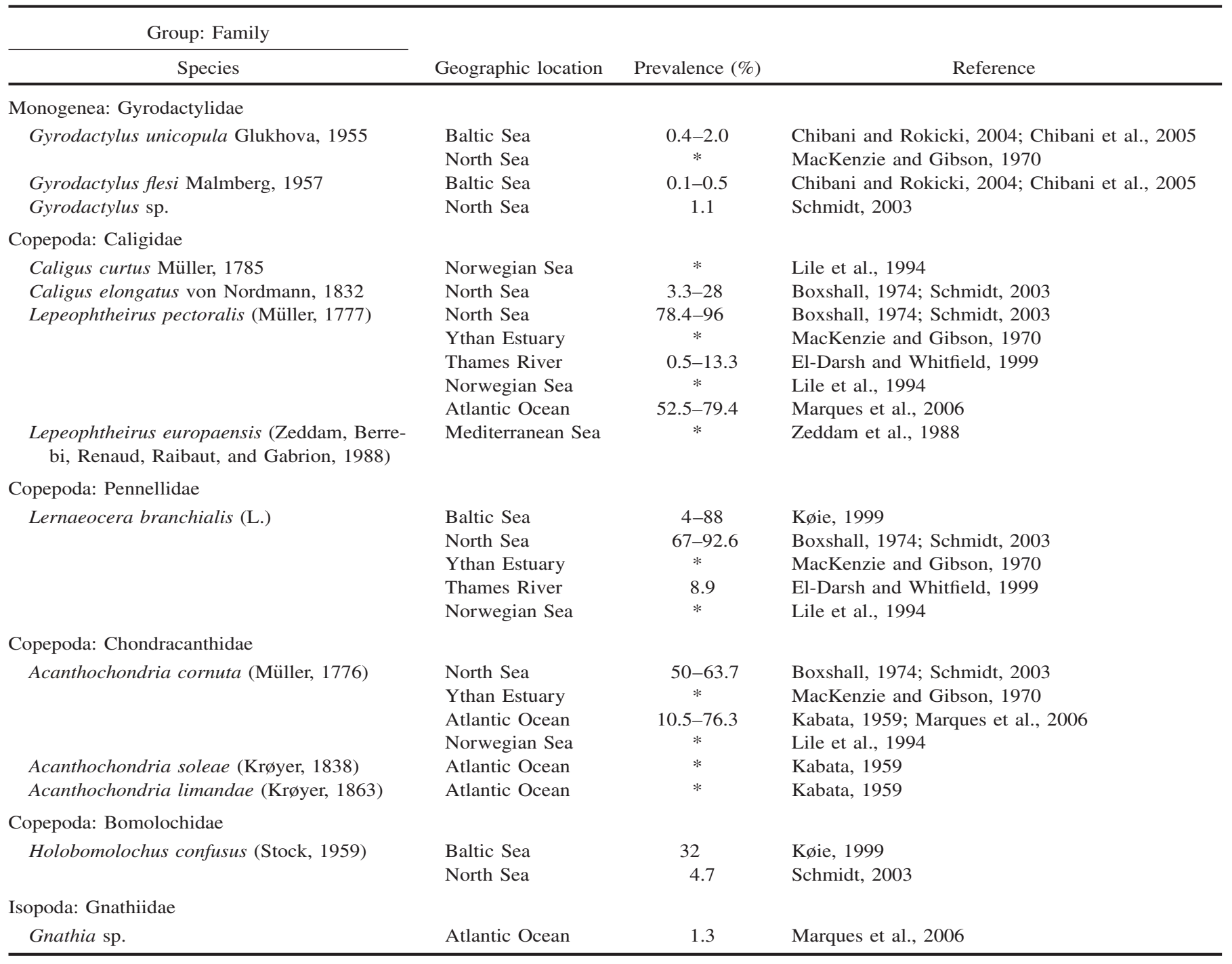

* Present.

the European flounder, P. flesus (L.), and reported in different studies of the literature (see Table I). However, for south European waters, only a single record indicating a flounder's infection by a new species, $L e$ peophtheirus europaensis, in the Mediterranean Sea (Zeddam et al., 1988), and a survey reporting flounder's infection by 3 different ectoparasite species in the south-central Portuguese coast (Marques et al., 2006), are known. Indeed, as far as we are aware, no parasitological survey has yet been conducted for flounders off the northern Portuguese coast, the geographic area where the economic income from flounder fishing is most important. Moreover, according to Lile et al. (1994), fish parasite communities often vary considerably in composition over short to moderate distances. Therefore, the main aim of the present study was to characterize the flounder's metazoan ectoparasite assemblage along the north-central Portuguese coast from different sampling locations.

On 2 and 8 September 2005, 120 flounders from 4 locations off the north-central Portuguese coast, i.e., Viana do Castelo (VC) $\left(41^{\circ} 40^{\prime} \mathrm{N}\right.$, $\left.8^{\circ} 50^{\prime} \mathrm{W}\right)$, Matosinhos (M) $\left(41^{\circ} 10^{\prime} \mathrm{N}, 8^{\circ} 42^{\prime} \mathrm{W}\right)$, Aveiro (A) $\left(40^{\circ} 38^{\prime} \mathrm{N}\right.$, $8^{\circ} 45^{\prime} \mathrm{W}$ ), and Figueira da Foz (FF) $\left(40^{\circ} 8^{\prime} \mathrm{N}, 8^{\circ} 52^{\prime} \mathrm{W}\right)$ (Fig. 1), were collected for examination of metazoan ectoparasites. In each location, 30 fish were collected by random sampling from the nets of local fishing boats. All the fish were kept frozen at $-20 \mathrm{C}$ until they could be examined. Each specimen was weighed (mean \pm SD [minimum-maxi- mum $]=279.2 \pm 172.8[160.7-1,090.4] \mathrm{g}[\mathrm{VC}] ; 314.5 \pm 217.6[139.4-$ $1,124.0]$ g $[\mathrm{M}] ; 267.4 \pm 122.0$ [113.6-613.8] g [A]; $409.9 \pm 207.3$ [158.4-836.2] g [FF]), measured (27.6 \pm 3.7 [24.2-42.8] cm [VC]; 28.7 $\pm 4.9[23.5-42.7] \mathrm{cm}[\mathrm{M}] ; 27.5 \pm 4.3[19.8-38.6] \mathrm{cm} \mathrm{[A]} ; 30.9 \pm 5.0$ [23.6-41.6] cm [FF]), and sexed (20 males and 10 females [VC]; 10 males and 20 females [M]; 9 males and 21 females [A]; 11 males and 19 females $[\mathrm{FF}]$ ). The body skin, eyes, fins, branchial chambers (subopercular surfaces, walls, gill arches, and pseudobranchiae), and nasal and buccal cavities were examined for metazoan ectoparasites using a stereomicroscope. Collected specimens were cleaned and then fixed in $70 \%$ alcohol. Later, copepods were cleared in $90 \%$ lactic acid (Humes and Gooding, 1964). Parasites were identified according to Naylor (1972) and Bruce (1987) for Isopoda, and to Kabata $(1979,1992)$ for Copepoda. It was not possible to identify the gnathiid pranizae at the species level because the identification keys require adult male specimens that were not found in our survey. Nevertheless, all the female larvae presented the same morphological type, which is, presumably, an indication of a single species.

After evaluating the sites of parasite infection on the host's body surface, the following ecological parameters were determined according to Bush et al. (1997) for each of the 4 sampled locations: prevalence (number of infected fish/percentage of infected fish [95\% confidence 


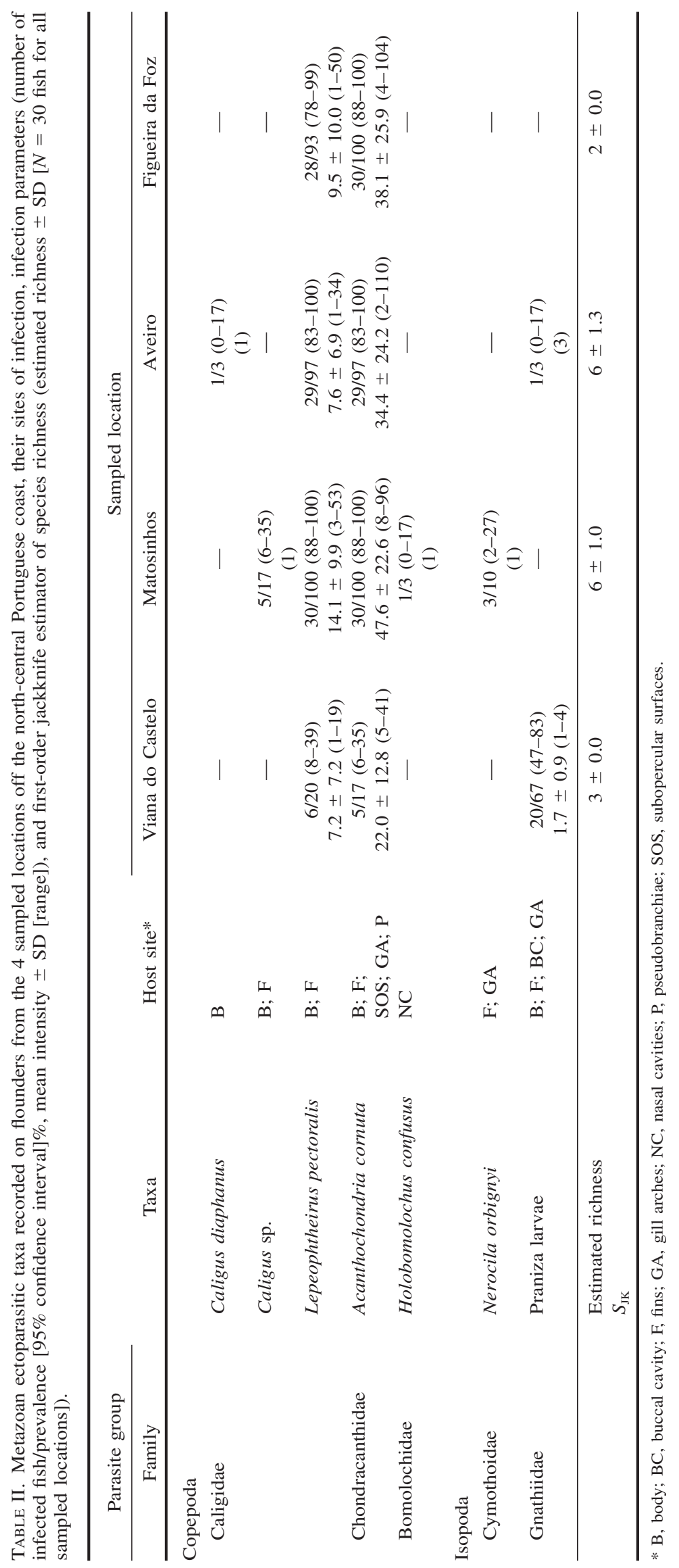




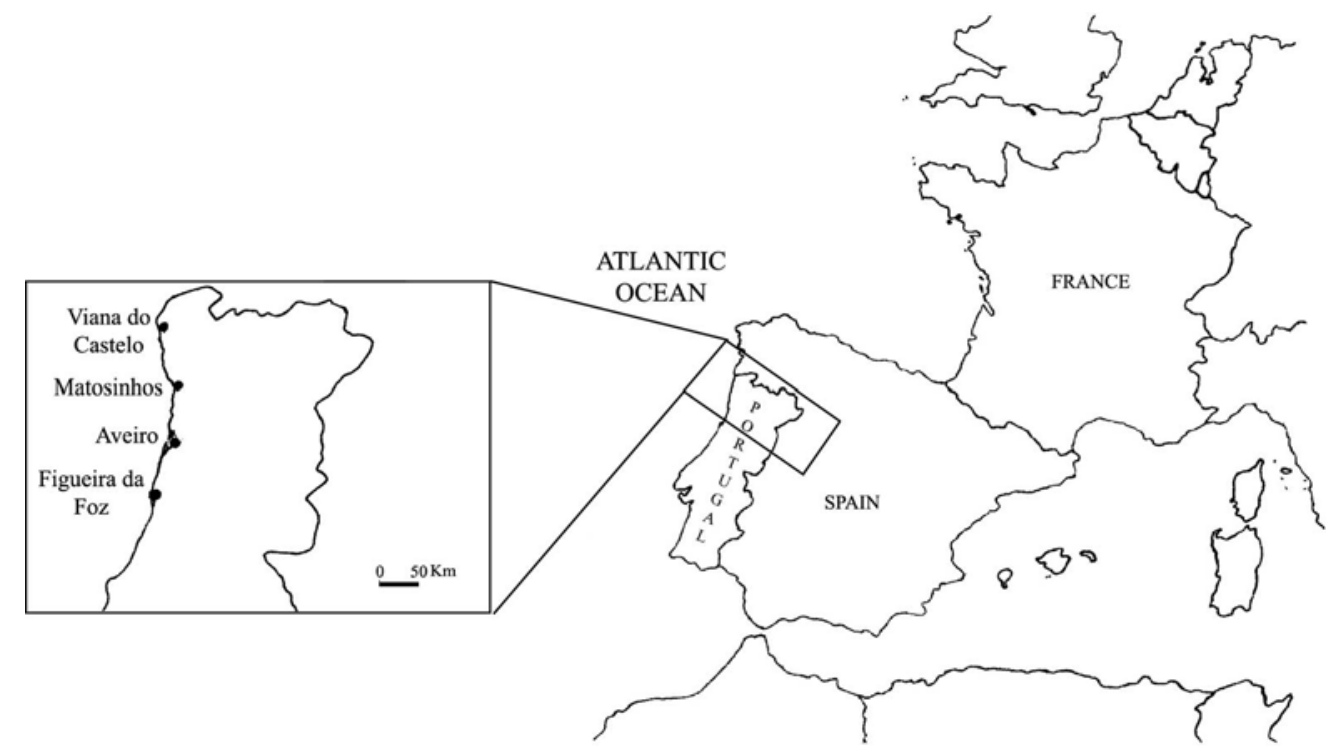

Figure 1. Geographic location of the 4 sampled areas (VC, Viana do Castelo; M, Matosinhos; A, Aveiro; and FF, Figueira da Foz) along the north-central Portuguese coast.

interval]) and mean intensity $\pm \mathrm{SD}$ (range). Besides that, the first-order jackknife estimator of species richness $\left(S_{\mathrm{IK}}\right)$ rounded to the nearest integer and respective standard deviation values were evaluated using EstimateS software (Colwell, 2005).

Parasites of 7 different taxa were identified on the flounders examined: Caligus diaphanus von Nordmann, 1832, Caligus sp., and Lepeophtheirus pectoralis (Müller, 1777) (Copepoda: Caligidae); Acanthochondria cornuta (Müller, 1776) (Copepoda: Chondracanthidae); Holobomolochus confusus (Stock, 1959) (Copepoda: Bomolochidae); Nerocila orbignyi (Guérin-Méneville, 1832) (Isopoda: Cymothoidae); and praniza larvae (Isopoda: Gnathiidae) (Table II). Infected host specimens were quite common, varying from 21 fish (70 [51-85]\%) off Viana do Castelo to 30 fish (100 [88-100]\%) off Matosinhos, Aveiro, and Figueira da Foz. Multiple infections were more frequent off Matosinhos, with all the infected host specimens (30 fish/100 [88-100]\%) harboring more than 1 parasite species, followed by Aveiro and Figueira da Foz (28 fish/93 [78-99]\%), and Viana do Castelo (7 fish/23 [10-42]\%). Copepod specimens were found on 7 (23 [10-42]\%) fish off Viana do Castelo and all (30/100 [88-100]\%) fish off Matosinhos, Aveiro, and Figueira da Foz. Isopods were found on 20 (67 [47-83]\%), 3 (10 [2$27] \%)$, and 1 (3 [0-17]\%) fish off Viana do Castelo, Matosinhos, and Aveiro, respectively. In contrast to what was previously described for the northern Europe flounder populations, and similar to what was observed in the south-central Portuguese coast, neither Lernaeocera branchialis (L.) nor any monogenean species was found during our study.

The infection of the European flounder P. flesus off the north-central Portuguese coast by ectoparasitic metazoans seems to be quite common, judging by the total number of infected fish found in our study. Furthermore, copepods were the most frequent parasites, whereas the isopods occurred only on rare occasions. With the exception of $C$. diaphanus, Caligus sp., and $N$. orbignyi, which, as far as we know, are new host records, all the other species have already been recorded on flounders from the Atlantic Ocean, and from the North, Norwegian, and Baltic seas.

The number of parasitic species recorded varied across locations, ranging between 2 and 5. However, while in $\mathrm{VC}$ and $\mathrm{FF}$ the observed and estimated richness values coincided, in $\mathrm{M}$ and $\mathrm{A}$ they did not, thereby indicating that the true species richness for the latter locations is higher than the one observed in our survey. The minimum value documented for the observed species richness was recorded for Lepeophtheirus pectoralis and A. cornuta, 2 species common to all the sampled locations. In fact, prevalence and intensity values recorded for these 2 species suggest that they are probably common parasites of flounders throughout the north-central Portuguese coast. Both copepods were dominant off Matosinhos, Aveiro, and Figueira da Foz, whereas off Viana do Castelo the highest prevalence value was recorded for gnathiid pranizae. In the North Sea, Lepeophtheirus pectoralis and A. cornuta also appear to be common parasites of the European flounder (Boxshall, 1974; Schmidt, 2003). All other identified parasites, i.e., C. diaphanus, Caligus sp., H. confusus, and $N$. orbignyi, exhibited comparatively lower prevalence and total intensity values, indicating that they are probably not common in flounders from the studied area. For the latter 4 species, differences in host age may help to explain their diverse occurrence on the fish samples. Moreover, all were absent from FF, the sampling location where older fish, i.e., fish possessing higher mean total weight and length values, were collected. The absence of Lernaeocera branchialis, a parasite that can constitute a severe pest with significant economic impact (Kabata, 1979), is noteworthy, since this species is a common parasite on flounders from the North (Schmidt, 2003) and Baltic Seas (Køie, 1999). This result is probably related to the absence of the main definitive host species (gadoid fishes) from the area under study (Kabata, 1979; Svetovidov, 1986).

We thank the Portuguese Science and Technology Foundation for F.C.'s grant SFRH/BM/23063/2005, and David Gibson, Nuno Formigo, and 2 anonymous referees for their valuable comments on the manuscript.

\section{LITERATURE CITED}

Boxshall, G. 1974. Infections with parasitic Copepods in North Sea marine fishes. Journal of the Marine Biological Association of the United Kingdom 54: 355-372.

BRUCE, N. 1987. Australian species of Nerocila Leach, 1818, and Creniola $\mathrm{n}$. gen. (Isopoda: Cymothoidae), crustacean parasites of marine fishes. Records of the Australian Museum 39: 355-412.

Bush, A., K. Lafferty, J. Lotz, and A. Shostak. 1997. Parasitology meets ecology on its own terms: Margolis et al. revisited. Journal of Parasitology 83: 575-583.

Chibani, M., AND J. Rokicki. 2004. Seasonal occurrence of parasites of flounder Platichthys flesus (L.) from the Gulf of Gdańsk. Oceanological and Hydrobiological Studies 33: 17-30.

- A. KiJewSKA, AND J. Rokicki. 2005. Sex and age of flounder Platichthys flesus (L.) and parasitic infection in the Gulf of Gdańsk. Oceanological and Hydrobiological Studies 34: 85-96.

Colwell, R. 2005. EstimateS: Statistical estimation of species richness and shared species from samples. Version 7.5. User's guide and application published at: http://purl.oclc.org/estimates.

El-DaRSH, H., AND P. WhitFIELD. 1999. The parasite community infecting flounders, Platichthys flesus, in the tidal Thames. Journal of Helminthology 73: 203-214. 
Humes, A., AND R. Gooding. 1964. A method for studying the external anatomy of copepods. Crustaceana 6: 238-240.

KabATA, Z. 1959. Ecology of the genus Acanthochondria Oakley (Copepoda Parasitica). Journal of the Marine Biological Association of the United Kingdom 38: 249-261.

1979. Parasitic Copepoda of British fishes. The Ray Society, London, U.K., 468 p.

- 1992. Copepods parasitic on fishes. Synopses of the British fauna (new series), No. 47. Universal Book Services/Dr. W. Backhuys, Oegstgeest, The Netherlands, $264 \mathrm{p}$.

KøIE, M. 1999. Metazoan parasites of flounder Platichthys flesus (L.) along a transect from the southwestern to the northeastern Baltic Sea. ICES Journal of Marine Science 56: 157-163.

Lile, N., O. Halvorsen, AND W. Hemmingsen. 1994. Zoogeographical classification of the macroparasite faunas of four flatfish species from the northeastern Atlantic. Polar Biology 14: 137-141

LuCAS, M., AND E. BARAS. 2001. Migration of freshwater fishes. Blackwell Science Ltd., Oxford, U.K., 420 p.

MackenZIE, K., AND D. Gibson. 1970. Ecological studies of some parasites of plaice Pleuronectes platessa L. and flounder Platichthys flesus (L.). In Aspects of fish parasitology, Symposia of the British Society for Parasitology, A. Taylor and R. Muller (eds.). Blackwell Scientific Publications, Oxford, U.K., p. 1-42.
Marques, J., C. Teixeira, and H. Cabral. 2006. Differentiation of commercially important flatfish populations along the Portuguese coast: Evidence from morphology and parasitology. Fisheries Research 81: 293-305.

NAYLOR, E. 1972. British marine isopods. The Linnean Society of London. Synopses of the British Fauna (New Series), No. 3. Academic Press, London, U.K., 85 p.

Schmidt, V. 2003. Parasites of European flounder (Platichthys flesus L.) from the German Bight, North Sea, and their potential use in ecosystem monitoring. Ph.D. Thesis. Universität Hannover, Kiel, Russia, $154 \mathrm{p}$.

Sobral, D., And J. Gomes. 1997. Peixes litorais - Estuário do Sado. Instituto da Conservação da Natureza, Lisboa, Portugal, 54 p.

Svetovidov, A. 1986. Gadidae. In Fishes of the northeastern Atlantic and the Mediterranean, Vol. II, P. Whitehead, M.-L. Bauchot, J.-C. Hureau, J. Nielsen, and E. Tortonese (eds.). Unesco ed., Paris, France, p. 680-710.

Zeddam, J., P. Berrebi, F. Renaud, A. Raibaut, and C. Gabrion. 1988. Characterization of two species of Lepeophtheirus (Copepoda, Caligidae) from flatfishes. Description of Lepeophtheirus europaensis sp. nov. Parasitology 96: 129-144.

\section{Early Migration of Sarcocystis neurona in Ponies Fed Sporocysts}

E. Elitsur, A. E. Marsh, S. M. Reed ${ }^{\star}$, J. P. Dubey†, M. J. Oglesbeeł, J. E. Murphy ${ }^{\star}$, and W. J. A. Saville§, Department of Veterinary Preventive Medicine, College of Veterinary Medicine, The Ohio State University, Columbus, Ohio 43210-1092; *Department of Veterinary Clinical Sciences, College of Veterinary Medicine, The Ohio State University, Columbus, Ohio 43210-1092; +United States Department of Agriculture, Agricultural Research Service, Animal and Natural Resources Institute, Animal Parasitic Diseases Laboratory, Beltsville, Maryland 20705-2350; łDepartment of Veterinary Biosciences, College of Veterinary Medicine, The Ohio State University, Columbus, Ohio 43210-1092; §To whom correspondence should be addressed.e-mail: saville.4@osu.edu

ABSTRACT: Sarcocystis neurona is the most important cause of equine protozoal myeloencephalitis (EPM), a neurologic disease of the horse. In the present work, the kinetics of $S$. neurona invasion is determined in the equine model. Six ponies were orally inoculated with $250 \times 10^{6}$ $S$. neurona sporocysts via nasogastric intubation and killed on days 1 , $2,3,5,7$, and 9 postinoculation (PI). At necropsy, tissue samples were examined for $S$. neurona infection. The parasite was isolated from the mesenteric lymph nodes at 1, 2, and 7 days PI; the liver at 2, 5, and 7 days PI; and the lungs at 5, 7, and 9 days PI by bioassays in interferon gamma gene knock out mice (KO) and from cell culture. Microscopic lesions consistent with an EPM infection were observed in brain and spinal cord of ponies killed 7 and 9 days PI. Results suggest that $S$. neurona disseminates quickly in tissue of naive ponies.

Equine protozoal myeloencephalitis (EPM) is a serious neurologic disease and Sarcocystis neurona is the most important cause (Dubey et al., 1991). Sarcocystis neurona has a 2-host life cycle, including a meateating definitive host, the opossums Didelphis virginiana and Didelphis albiventris (Dubey, Lindsay, Kerber et al., 2001; Dubey, Lindsay, Saville et al., 2001). There is a wide range of intermediate hosts, including the raccoon (Dubey, Saville et al., 2001), armadillo (Cheadle, Tanhauser et al., 2001), skunk (Cheadle, Yowell et al., 2001), sea otter (Dubey et al., 2002), and the domestic cat (Dubey and Hamir, 2000; Dubey et al., 2000; Turay et al., 2002). The horse is considered an aberrant intermediate host (Dubey, Lindsay, Saville et al., 2001). Schizonts and merozoites are the only stages known in the horse, and they are found only in the central nervous system (CNS) following an uncharacterized migratory route. Attempts to demonstrate $S$. neurona in tissues of horses fed sporocysts have been unsuccessful despite the fact that horses developed neurological signs (Fenger et al., 1997; Lindsay et al., 2000; Cutler et al., 2001; Saville et al., 2001; Sofaly et al., 2002). In the present article, we have attempted to follow the migration of $S$. neurona in tissues of ponies by orally inoculating them with large numbers of sporocysts and examining at shorter postchallenge intervals.

Eight seronegative ponies (Table I) were randomly assigned to treatment $(n=6)$ or control $(n=2)$ groups and housed in separate stalls. Neurologic examinations were conducted before the initiation of the project and daily there after, including the date of termination. The examinations were performed by a coauthor (S.M.R.). Physical examinations were also performed daily. On day 0, cerebral spinal fluid (CSF) and blood samples were collected from each horse, and treatment ponies were inoculated with sporocysts via nasogastric intubation with $250 \times 10^{6}$ sporocysts $(25 \mathrm{ml})$ and $120 \mathrm{ml}$ doses of phosphate buffered saline (PBS) to ensure complete dosing. The sporocysts were of the raccoon isolate $\mathrm{SN} 37-\mathrm{R}$ and had been obtained from the intestines of the laboratory-raised opossums fed tissues of experimentally infected raccoons as described (Sofaly et al., 2002; Stanek et al., 2002).

Control ponies were given saline solution $(25 \mathrm{ml})$ and $120 \mathrm{ml}$ doses of PBS via the nasogastric tube. Disposable gloves and plastic boots were used upon entrance into the control ponies' stalls to avoid crosscontamination and were immediately discarded afterwards. An empty stall was maintained between the control ponies and treatment ponies as well. Blood for serology was collected daily (days 1-9) and for buffy coat culture on terminal dates. Treatment ponies were randomly assigned to serial killing on days 1, 2, 3, 5, 7, and 9 PI, and the control ponies were killed on days 3 and 9 PI. Ponies were humanely killed with an overdose of Euthasol euthanasia solution (Delmarva Laboratories, Midlothian, Virginia), and CSF was collected via the atlantooccipital space at postmortem.

Necropsy was performed on all ponies. At necropsy, samples of lung, liver, mesenteric lymph nodes, and mesenteric artery were removed aseptically for $S$. neurona isolation. Additional tissue samples were fixed in $10 \%$ buffered formalin for routine microscopic examination, including the heart, lung, diaphragm, liver, spleen, adrenal gland, kidney, tongue, mesenteric lymph node, mesenteric artery, cecum, sciatic 